\title{
From the Instrument of Delivery to the Actual Agent of Harm: Fighting the Criminal Purchase of Ammunition
}

\author{
Marsha S. de Vries
}

Published online: 15 April 2012

C The Author(s) 2012. This article is published with open access at Springerlink.com

\begin{abstract}
The illegal trade in ammunition in the Netherlands seems to be a small-scale problem. However, as a result of high profits and a small chance of being caught, it is an extremely attractive criminal activity for malicious individuals. The criminal purchase of ammunition is facilitated by weaknesses in the logistic supply chain for legal ammunition, current legislation on the purchase, possession, transport and use of ammunition and the inadequacy with which Dutch government agencies enforce the laws. The fight against the criminal purchase of ammunition could benefit from the adoption of an automated registration system by arms dealers, the use of a different type of freighting method for legal ammunition transport and a common approach by European law enforcement agencies.
\end{abstract}

Keywords Ammunition · Gun policy · Script analysis

\section{Introduction}

Gun crime is an issue that received little attention from the Dutch police until the 1990s. Interest in the topic increased when in the course of the 1990s there was a decline in the number of firearms seized, even though the number of shooting incidents increased (Korps landelijke politiediensten 2006). Different levels within the Dutch police organization, local and supra-regional, highlighted both illicit firearms trafficking (the supply side of the illegal firearms market) and the possession and use of firearms (the demand side of the illegal firearms market). But the current Dutch approach has its limitations, as it gives insufficient priority to the illegal firearms trade, for example. There is often little or no research into the origin of seized illegal firearms and their suppliers; firearms are only seen as an incidental 'catch'. In addition, the approach is hampered by the lack of common firearms legislation in the European Union, the erosion of international border controls as a result of the further

M. S. de Vries $(\bowtie)$

School for Management and Governance, Department of Social Risks \& Safety Studies, University of Twente, P.O. Box 217, 7500 AE Enschede, The Netherlands

e-mail: m.s.devries@utwente.nl 
expansion of the European Union, and the closed nature of the illegal firearms trade (De Vries 2008).

The way the Dutch police address the demand side of the illegal firearms market (i.e. the possession and use of illegal firearms) has its limitations, too. Between 1500 and 2000 firearms capable of discharging live ammunition are seized in the Netherlands every year, mostly semi-automatic pistols, revolvers and rifles. Recently there has been a decrease in the number of firearms seized (Dienst Nationale Recherche 2008). Specific measures, such as stop-and-search and drop-off operations, seem to have little effect. Fewer illegal firearms are seized every year during stop-and-search operations; 56 firearms were seized in 2003, whereas only 16 firearms were seized in 2006. Only 55 firearms were voluntarily surrendered during drop-off operations in 2006 (Van der Zee and Ham 2006). This represents a mere fraction of the total number of illegal firearms in circulation in the Netherlands; in 2002, Spapens and Bruinsma (2002) estimated the number of illicit firearms at 85,000 to 125,000 and in 2005 the number of illegal gun owners owning at least one illicit firearm was estimated at 54,000 (Bruinsma and Moors 2005). So much for the possession of illegal firearms. The use of illegal firearms in the Netherlands fluctuates and seems to be declining (Korps landelijke politiediensten 2006). In 2009, more than one quarter of the victims of murder or manslaughter in the Netherlands were killed with a firearm (Centraal Bureau voor de Statistiek 2011).

The Dutch approach to the illegal firearms market has so far focused on the trafficking, possession and use of firearms, while the nature and origin of the ammunition used by criminals is ignored. This, according to foreign firearms studies, is a bad decision. Both Bourne and Berkol (2006) and Anders (2006a) note that it is arguably more important to address the illicit trade in ammunition than to fight the illicit trade in firearms; a regular supply of ammunition is critical to the continuation of armed conflict and criminal activity and a shortage of bullets can lead to a decrease in or even abandonment of the use of firearms. Tita et al. (2006) add that, apart from the fear inspired by the use of a firearm, it is clear that a firearm without ammunition is less dangerous than a loaded one. The gun policy could take an example from the public health policy on drugs (2006: 308): "Unlike the public health view on drug policy, which recognizes the importance of limiting access to both the agent of harm (the narcotic) and the instrument of delivery (for example, syringe), gun policy has focused primarily on limiting access to the instrument of delivery, firearms, while eschewing efforts to limit access to ammunition, the actual agent of harm".

The illicit trade in ammunition is a crucial element in the fight against gun crime, especially since previous research (e.g. Anders 2006a; Bourne and Berkol 2006; Tita et al. 2006) showed that even in areas where gun violence is prevalent, firearms are easier to obtain than ammunition. According to Tita et al. (2006), this suggests that stepping up efforts to prevent criminals gaining access to ammunition is more successful in combating gun crime than further restricting access to firearms.

\section{Methodology}

The main question that will be answered in this article is: "How does ammunition end up in the hands of criminals and how can the criminal purchase of ammunition be combated?". This question is answered using two different research methods, namely an analysis of information from computerised systems, and interviews. First, information from the National Collection of Bullets and Cartridge Cases of the Dutch Forensics Institute was analysed to gain an insight into the nature and distribution of the ammunition found amongst Dutch 
criminals. The information related to the period 1999-2008 and covered 3286 shooting incidents. Subsequently, ten interviews were conducted with a total of 15 experts within and outside the police who could contribute in any way to the picture of the illicit trade in ammunition amongst Dutch criminals. The interviews were held between September 2009 and January 2010. The police respondents are members of the firearms training staff of the Police Academy of the Netherlands, the chairman of the firearms expert group of the National Firearms Platform, and firearms experts from the regional police forces Amsterdam-Amstelland, Rotterdam-Rijnmond, and Haaglanden. These three police forces confiscate most of the firearms and live ammunition of all Dutch police forces and so the information provided by these forces was assumed to be the best available. The experts outside the police force who were interviewed were a member of the Dutch Forensics Institute, who knows about the types of ammunition and calibres used in criminal shootings. In addition, a legal arms dealer (also a board member of the Dutch Association for the Arms Trade), a sport shooter, an ammunition reloader, and three members of the Dutch Association for the Study of Ammunition and Ballistics were questioned. They discussed the size of the ammunition flow and the routes involved in transferring ammunition to the illegal market, such as theft from the legal arms trade and the sports shooting industry.

\section{Crime Script}

My analysis of the illegal trade in ammunition adopts a script perspective (also see De Vries 2011). The concept of a script has been borrowed from cognitive science; it was introduced into criminology by Cornish in 1994. Cornish describes script analysis (1994: 160) as: “(...) a way of generating, organizing and systematizing knowledge about the procedural aspects and procedural requirements of crime commission". Studying crime from a script perspective could result in more specific and detailed information about crime commission, which would help to develop successful situational crime prevention policies by drawing attention to a fuller range of possible intervention points. The script approach emphasizes the procedural nature of criminal behaviour at the individual or group level. The script is a map of a given criminal procedure; it is made up of scenes that present episodes or logistical steps that occur during the process of committing a certain crime. Each of these scenes can be broken down into a variety of facets. Facets are alternative methods of carrying out the action particular to each scene (Cornish 1994: 173). The crime script used in this research consists of five scenes: (1) production, (2) procurement, (3) transportation, (4) sales and (5) possession and use. The crime script of ammunition with its scenes and facets is presented in table 1 and is clarified in the following section.

\section{Results}

\section{Scene 1 Production}

The vast majority of ammunition found amongst Dutch criminals has been legally produced. The Netherlands has had no domestic ammunition manufacturers for several years now. The ammunition used in the Netherlands appears to be produced predominantly in other Western European countries, especially the Czech Republic, Italy and Switzerland. It is generally difficult to establish the location where the ammunition encountered in the Dutch criminal environment is produced. Some manufacturers produce all the components of ammunition, 


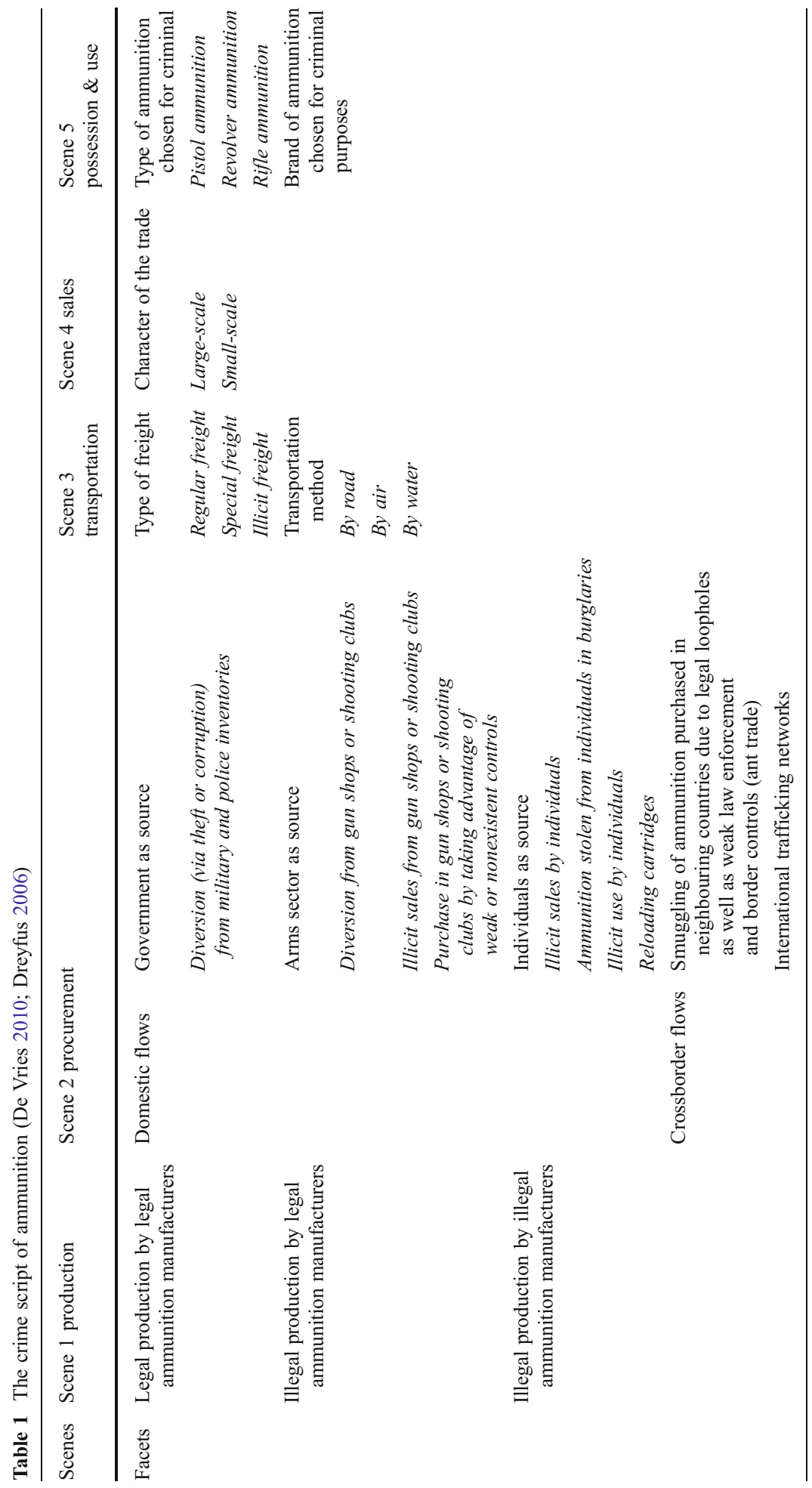


while others produce only some of the components and the ammunition is then made up later, in another location. There are also manufacturers that only make up ammunition from components manufactured elsewhere. Furthermore, some ammunition is produced at the request of a buyer. Although all complete ammunition bodies should be marked after production, the markings do not provide adequate information on where (the various components of) the cartridges were made. Moreover, even if it can be determined who the manufacturer is, it is often impossible to determine who the first and subsequent legal owners of the ammunition were. This is partly due to the fact that lots with similar markings are usually divided and sold to different buyers. It is frequently not clear who the last legal owner of the ammunition was and when the ammunition came into the possession of criminals (Anders 2006b).

In theory, ammunition manufacturers could exploit an illegal production line, in addition to legal production patterns, or they could transfer legally produced ammunition through illegal channels. However, there are no indications that the ammunition purchased by criminals in the Netherlands was obtained through such lines. Nor does there appear to be any large-scale illicit manufacture of ammunition. Ammunition experts agree that given the limited market in the Netherlands, large-scale, illegal production of ammunition would not be profitable.

\section{Scene 2 Procurement}

Illegal ammunition flows are usually assumed to proceed via the same pathways as the illegal flow of firearms. According to Bourne and Berkol (2006), to some extent this may well be so, but they emphasize some important differences between the two types of goods, differences which affect the work of policy makers. They point out, for example, that guns can be used many times, while ammunition cannot. Therefore, in periods of intense criminal violence or armed conflict, a continuous influx of ammunition is needed. Criminals can procure ammunition via various routes, either on the domestic market or via cross-border flows (Bourne and Berkol 2006; Dreyfus 2006).

\section{Procurement on the Domestic Market}

The first procurement route is on the domestic market (Bourne and Berkol 2006: 102): "Recipients of illicit ammunition in situations of conflict and crime obtain it in numerous ways, many of which do not involve international trafficking, including a range of local processes of theft, capture, and purchases from illicit markets within states". Ammunition can be stolen from police and military stockpiles, while corrupt staff of the relevant agencies can play a crucial role in this process. Additionally, ammunition can be stolen from legal gun dealers and individuals who are in legal or illegal possession of one or more firearms. By deception, legal gun dealers and private individuals (e.g. sports shooters, hunters and collectors of ammunition) can wittingly or unwittingly provide ammunition to criminals. Finally, the expended ammunition casings can be reloaded and re-used for criminal purposes; ammunition can also be illegally produced.

Public services may function as a source of ammunition for criminals in several ways. In the first place, ammunition can be stolen from military stockpiles as well as from individual soldiers. In practice, it seems that there are no large-scale thefts of defence ammunition in the Netherlands. Defence ammunition is rarely found in the possession of criminals since the calibres used by the military are different from the calibres used by criminals. The police can also serve as a source of illegal ammunition. However, like the military, it seems that in 
practice the police are not a major supplier of ammunition to criminals. Thefts of large quantities of police firearms and ammunition are unknown in the Netherlands. Police ammunition has occasionally been found at a crime scene. Presumably, it was taken by individual police officers, but not in large quantities and not on a regular basis.

Furthermore, ammunition may leak into the criminal environment through the legal industry (arms dealers, shooting clubs). Legal gun dealers in the Netherlands generally have good security and burglaries are infrequent. When a burglary does occur, as in 2009 at a gun shop and shooting club in Amsterdam, firearms are generally the intended target, with ammunition only a secondary consideration. The average arms dealer does not hold large stocks of ammunition. Another route by which ammunition can flow into the hands of criminals is through the illegal sale of ammunition by arms dealers and shooting clubs. In theory, arms dealers can tamper with their bookkeeping in order to divert ammunition and firearms to criminals, but according to firearms experts of the Dutch police it is unlikely that this happens in the Netherlands. Gun dealers keep records of all purchases and sales of arms and ammunition and the records are submitted to the police every month. However, the degree to which these records are checked depends entirely on the capacity of the police; practice the controls turn out to be fairly infrequent and relatively superficial in most Dutch police regions. Weak controls (or their absence) on the purchase of ammunition by individuals may also facilitate its criminal purchase. In the Netherlands one is only allowed to purchase ammunition with a permit or a game license, so there will always be a licensee (sports shooter, hunter, collector) who acts as an intermediary between the legal arms dealer and the criminal who wants to purchase ammunition, unless the licensee is planning to use the ammunition for criminal purposes himself. The transfer of ammunition from malicious individuals to criminals is a real danger in the Netherlands, as it appears below. There was no evidence found of conscious involvement of legal arms dealers in this aspect.

Several requirements must be met if an individual wants to be eligible for a permit (sports shooters, collectors) or a game license (hunters). These are set out in the Arms and Ammunition Act (Wet wapens en munitie) for sports shooters and collectors and in the Flora and Fauna Act (Flora- en faunawet) for hunters. The applicant should be at least 18 years old, be in possession of a certificate of good conduct, and should be a member of a shooting club affiliated with the Royal Dutch Shooters Association (Koninklijke Nederlandse Schutters Associatie) or a club affiliated with the European Cartridge Research Association, an example being Dutch Association for the Study of Ammunition and Ballistics (Nederlandse Vereniging ter Bestudering van Munitie en Ballistiek). Prior to the application, he should have been a prospective member of one of the aforementioned associations for at least one year. For all types of applicants (sports shooters, collectors and hunters) there are additional requirements and there must be no presumption of abuse. Individuals may then, on presentation of their permit or game license, purchase an unlimited number of cartridges from a dealer. Ammunition can also be purchased from shooting clubs. The purchase of ammunition is recorded by the arms dealer; however, there is no check on individual buyers based on these records. The system of registration has been developed to check on the dealer, not the hunter, collector or sports shooter who purchases the ammunition. So when a hunter, collector or sports shooter buys large amounts of ammunition from different dealers, it remains unknown to both dealers and law enforcement agencies. The amount of ammunition used by individuals on the firing range or elsewhere is not recorded. Individuals may carry up to 2000 cartridges and store 10,000 cartridges at home, even though there would seem to be no valid reason for individuals to hold such large quantities of cartridges in stock. One respondent, who works at the Police Academy of the Netherlands, commented: "Even for an avid sports shooter it is difficult to shoot 3000 rounds within two month". The storage of 
firearms and ammunition by individuals is checked by a special department of the Dutch regional police forces. These checks are based on Article 45 of the Dutch Arms and Ammunition Act, in accordance with the formal framework of administrative law; it forms no part of the criminal law. This implies that the police may, only with the permission of the licensee, check certain specifically defined places in the home of the licensee, i.e. the place where the weapon safe is located. If a sports shooter, hunter or collector states that control is inconvenient, a new appointment has to be made, thus giving him the opportunity to conceal any criminal activity. Despite the requirements imposed on persons who want to possess a firearm, a particular group of sports shooters are seen as the most likely source of ammunition for criminals. The restrictions in Dutch legislation and the way the Dutch police force fulfils its monitoring role, the type of ammunition used in shooting incidents and the high profit margins on ammunition on the illicit market mean that experts within and outside the police presume that the illegal trade in ammunition is a highly lucrative criminal activity with high yields and low risks, especially for sports shooters. A sport shooter commented: "It is not difficult to pilfer 2000 cartridges a year". Another respondent, a former police officer and sports shooter, estimated his potential success on the criminal path even higher, noting: "I could purchase 150,000 to 200,000 cartridges in a week".

Ammunition may also end up in criminal hands from burglaries and other forms of theft from individuals. In practice, burglaries take place in private homes and, in general, both firearms and ammunition are obtained that end up on the criminal market. Theft of ammunition from individuals seems to be no major problem, however, although in general it is unclear how much ammunition is in the possession of individuals; moreover, after a burglary or other form of theft, the exact amount of ammunition that was captured remains unknown.

Unlike other countries, ammunition reloading is not controlled in the Netherlands. Anyone who is legally allowed to own a firearm may reload cartridges for personal use and may sell reloaded ammunition to other licensees, provided this is done at cost. Ammunition is reloaded to improve the precision of cartridges. Properly reloaded ammunition can be fired more accurately. Experts point out that reloading ammunition is not difficult, but it is a very precise task, requiring technical knowledge and equipment. There seems to be a geographical difference between the degree to which reloaded ammunition is found at crime scenes in different parts of the Netherlands. In Amsterdam reloaded ammunition is regularly seized from criminals, whereas hardly any reloaded ammunition is found at crime scenes in Rotterdam and The Hague. An employee of the Dutch Forensics Institute estimates that currently less than one percent of the ammunition found in shooting incidents has been reloaded.

\section{Procurement Via Cross-Border Flows}

Ammunition can be procured by criminals not only through domestic channels but also via cross-border flows. Bourne and Berkol (2006) describe several methods of cross-border trade in ammunition. The most common method is known as the 'ant trade'. This involves cross-border smuggling of small lots of ammunition, generally for the markets in neighbouring countries. This type of ammunition smuggling thus has a predominantly regional character. Most ammunition is legally obtained by smugglers through retail purchase or is stolen from ammunition stocks held by the government or ammunition manufacturers before being smuggled across the border to illegal buyers. It also happens that ammunition legally obtained by individuals in one country is subsequently smuggled to another country. Although each transaction is small, the total number of transactions over a certain route to a particular destination can be substantial. According to Bourne and Berkol (2006), the ant 
trade is the most common form of smuggling; the method is more frequently encountered in the smuggling of ammunition than in the smuggling of illegal firearms. The methods used in the ant trade used are similar to those of the small-scale, cross-border smuggling of firearms and other illicit commodities, where porous borders and the concealment of merchandise are necessary conditions.

In 2008, a crime pattern analysis by the Dutch National Crime Squad concluded that ammunition is generally seized together with the weapons for which the ammunition was intended. No major illegal transports of ammunition were known to the Dutch police. The size of the consignments of confiscated ammunition ranged from a few cartridges to several thousand, though in general the quantities involved were relatively small. In relation to the Netherlands, the ant trade seems to be the most common smuggling method, although it was noted that the amount of information available was limited and of poor quality (Dienst Nationale Recherche 2008). More recently, no large-scale, cross-border smuggling of ammunition seems to have occurred in the Netherlands. Presumably, ammunition comes into criminal hands via the grey market; distribution channels which, while legal, are unofficial, unauthorized, or unintended by the legislator. Individuals may purchase ammunition from foreign arms dealers and transport a maximum of 1000 cartridges across the border (cf. Article 14, Weapons and Ammunition Act). According to ammunition experts, it is easy to buy ammunition from legal traders abroad, even without a permit or game license, and certain types of ammunition that are regulated in the Netherlands are freely available in neighbouring countries, such as hunting ammunition in Belgium. Several experts suspect that individuals with criminal intent purchase ammunition through legal gun dealers abroad. Due to the lack of border controls within the European Union, they run little risk of detection. There are no international criminal networks known to the Dutch police that smuggle ammunition to the Netherlands; the smallscale ant trade by malicious individuals seems to be prevalent. Table 2 summarizes the illegal ways in which ammunition can be procured.

Table 2 The procurement of ammunition (De Vries 2010)

Domestic flows

\section{Government as source}

Diversion (via theft or corruption) from military and police inventories

Arms sector as source

Diversion from gun shops or shooting clubs

Illicit sales from gun shops or shooting clubs

Purchase in gun shops or shooting clubs, taking advantage of weak or non-existent controls

Individuals as source

Illicit sales by individuals

Ammunition stolen from individuals in burglaries

Illicit use by individuals

Reloading cartridges

\section{Cross-border flows}

- Ant trade

- International trafficking networks
Certain, but occasionally and only small amounts

Probable, but occasional

Unlikely

Probable, on a relatively large scale, no indication of deliberate cooperation of the sector

Probable, on a relatively large scale

Certain, on a relatively small scale

Certain, but occasional

Certain, on a small scale, differs

between police regions

Probable, on a small scale, often in combination with firearms

Unlikely 


\section{Scene 3 Transportation}

Ammunition is classified as a dangerous good by the United Nations Committee of Experts on the Transport of Dangerous Goods. The United Nations guidelines in respect of dangerous goods are described in the European Agreement Concerning the International Carriage of Dangerous Goods by Road (EDR) of 2009. Ammunition is covered by Class 1 of the EDR (explosive substances and articles) and this mandates certain requirements regarding the transportation thereof (packaging methods, marking, etc.).

Ammunition that is legally imported to the Netherlands is transported in delivery trucks among the regular freight. The transportation of ammunition does not always seem to be done in a way that is desirable, nor with sufficient care, given the nature of the product. Ammunition in transit is often stored and transferred, and both during the delivery and the storage of the goods, ammunition can be and has been lost or stolen. The theft insurance pays, so there is no incentive for the supplier to change the way ammunition is transported and the customer will usually receive another consignment of ammunition. Two recent events illustrate the risks associated with the transportation of ammunition. The first example is that of a truck-trailer of a transport company carrying ammunition. A motorist driving behind the trailer saw a number of cartridges rolling from the truck. It turned out that a box containing ammunition was torn open and the door of the truck was not closed, so the ammunition fell out. On closer scrutiny, there appeared to be not a single document covering this freight. A second example concerns a consignment of ammunition ordered in the United States. A delivery service brought the ammunition to the delivery address, but the recipient was not at home. The driver put the box of ammunition under the bushes and put a note in the mailbox stating where the ammunition was to be found. The ammunition was found there by the recipient only later that night.

\section{Scene 4 Sales}

Little can be said for certain about the actual sales and transfers of ammunition to criminals. Various ammunition experts of the Dutch police say that they have the impression that the trade in ammunition is local in character; buyers and sellers are presumed to live in the same city. There is slightly more certainty about statements about the availability and price of illegal ammunition. Bourne and Berkol (2006) claim that the price level of illicit ammunition varies rapidly, following complex patterns. In the Netherlands, there seems to be a kind of false scarcity regarding the sale of illicit ammunition. According to the firearms experts of the regional police forces, the profit margins on ammunition are continuously relatively high; criminals would pay around 3 euro's for a cartridge while a sports shooter pays around 20 cents for a $9 \mathrm{~mm}$ cartridge. ${ }^{1}$ Moreover, a firearm is many times more expensive when it is supplied with ammunition. Nonetheless, experts have the impression that there is indeed sufficient ammunition in circulation in the Netherlands and, in contrast to the description given by authors such as Anders (2006a), Bourne and Berkol (2006), and Tita et al. (2006) of the worldwide ammunition market, they claim that ammunition is easy to obtain. The Netherlands has no known criminal ammunition dealers with large stocks at their disposal. Ammunition appears to be a durable good, which limits the size of the ammunition market. Whereas sports shooters and hunters, but also armed rebels, need a constant supply of ammunition, generally criminals seem to be satisfied with just a few cartridges. There are

\footnotetext{
${ }_{1}^{1} 1000$ rounds of $9 \mathrm{~mm}$ Sellier $\&$ Bellot cost around 200 euro (www.piroholsters.nl and www.kraleschietsport.nl, consulted on 15 February 2012).
} 
relatively few shooting incidents in the Netherlands in which large quantities of cartridges are fired.

\section{Scene 5 Possession \& Use}

In general, the Dutch police do not seize major quantities of ammunition, it is usually just a full magazine and a box containing a few cartridges of different brands. Based on the nature of confiscated ammunition, it seems that criminals use such ammunition as is available, combining different brands, a phenomenon that is often referred to as the use of street loads. The calibres and ammunition brands that are in circulation on the illicit ammunition market highly correspond to the calibres and brands on the legal market. The calibres $9 \mathrm{~mm}$ Parabellum and $7.65 \mathrm{~mm}$ Browning are the most popular. Calibre $6.35 \mathrm{~mm}$ Browning is also popular on the illicit market. This calibre is mainly used in converted (and thus illegal) firearms (De Vries 2011). Sellier \& Bellot, Fiocchi, Geco and Magtech (CBC) stand out in terms of brands. Criminals predominantly use pistol ammunition, with relatively less revolver ammunition. The nature of the revolver ammunition found at crime scenes is also similar the common sports shooting calibres; .357 Magnum and .38 Special turn out to be the most popular. Hunting ammunition is hardly found at crime scenes and when it is found, it is mainly in combination with sawn-off shotguns. The explanation for the limited use of rifles is probably that small arms (pistols, revolvers) are easier to transport and easy to obtain in the Netherlands.

\section{From Problem to Policy}

"In sum, while public and policy discourse may portray illicit transfers of ammunition for small arms and light weapons as being 'powerful lawbreakers' or criminal actors breaking laws in order to move illicit small arms ammunition around the globe, the predominant reality is that while such trafficking may occur - it is overshadowed by a wide range of processes that result from weak 'lawmakers' in which weak or limited legal frameworks and legal loopholes combine with weak enforcement of controls to create opportunities for illicit transfers to occur" (Bourne and Berkol 2006: 102). The illicit trade in ammunition can only be effectively combated when the legal trade in ammunition is strictly controlled. Bourne and Berkol (2006) suggest that in the current policy debate, illegal ammunition remains out of sight because insufficient weight is attached to controlling the legal trade in ammunition, which is an important observation in relation to the Dutch situation. Previous analysis has shown that ammunition may flow into the hands of criminals due to weaknesses in the legal logistic chain. In terms of the crime script, weak spots, and therefore targets for preventive measures, occur in the Procurement and Transport scenes. Specific attention should be paid to: (1) the link between arms dealers and licensees (particularly sports shooters); (2) cross-border purchases by individuals; and (3) the transportation and storage of ammunition by regular freight. These weaknesses are particularly vulnerable as enforcement and inspection agencies do not have a balanced view of the volume of cartridges in private possession, the controls on the possession of ammunition are infrequent, and police officers' knowledge of relevant legislation is inadequate.

In their study on the use of ammunition by criminals, Tita et al. (2006) emphasize the importance of having a view of the sales of ammunition to individuals. They say (2006: 309): "(...) there is reason to believe that targeting retail ammunition sales will in fact impact levels of firearm injury. (...) If it is true that for many criminals ammunition is scarce 
then effective screening procedures or transaction record keeping for ammunition purchases at retail outlets could be used to good effect in reducing an important supply line of ammunition". The first problem, the weak link between arms dealer and licensee, can partly be overcome by implementing the new accounting system for the arms trade that is currently being developed by the Dutch Association for the Arms Trade. Using this system, the dealers' records are digitized and the police can receive daily information from arms dealers on the import and sale of firearms and ammunition. The use of this system, for example in combination with a compulsory membership of the Association for the Arms Trade, could be linked to a system of certification of arms dealers in order to protect the integrity of the sector. If the accounting system is introduced, it would also have implications for monitoring and enforcement by the responsible authorities. Multiple purchases can easily be traced to the responsible permit holder, which would result in an increase in the knowledge of ammunition in private possession and greater focus in the police forces' monitoring activities. For this purpose, however, sufficient capacity should be freed and the police officers should develop greater expertise about ammunition. In addition, knowledge of the ammunition sales could be increased by limiting sales to gun shops only. Currently, ammunition can also be purchased through shooting clubs, which experts see as a potential risk as it distorts our knowledge of the nature and extent of legal ammunition sales.

A second weakness in the ammunition crime script is cross-border purchases of ammunition by individuals. This weakness could be strengthened through regional harmonization of laws and regulations concerning weapons and ammunition and by sharing intelligence and police information by European law enforcement agencies (also see Dreyfus 2006: 194). Although the Member States of the European Union have a great deal of freedom to design their own laws and regulations on firearms and ammunition, a positive development in this issue is EU directive $2008 / 51 / \mathrm{EC}^{2}{ }^{2}$ which states that in order to facilitate the tracing of firearms and to combat the illicit manufacturing of and trafficking in firearms, their parts and ammunition, the exchange of information between Member States should be improved. The ammunition used by Dutch criminals is legally produced abroad, as the Netherlands have no legal and (probably) no illegal producer of ammunition. Therefore, the ammunition that is in circulation in our country has crossed the Dutch border at some point, either legally or illegally. For both a better understanding of legal and illegal ammunition flows and for a more effective approach of individuals who facilitate the criminal purchase of ammunition, it is necessary to think and act across national borders. Ideally, a European approach regarding illicit ammunition should be accomplished, in which law enforcement agencies and ammunition manufacturers participate. An interesting development in this matter is the marking upon manufacturing of each firearm and elementary package of ammunition for identification and tracing purposes. Article 4, as amended by EU directive 2008/51/EC, states that for the purpose of identifying and tracing each assembled firearm, member states of the European union shall, at the time of manufacture of each firearm, either (a) require a unique marking, including the name of the manufacturer, the country or place of manufacture, the serial number and the year of manufacture (if not part of the serial number) or (b) maintain any alternative unique user-friendly marking with a number or alphanumeric code, permitting ready identification by all states of the country of manufacture. Furthermore, member states shall ensure that each elementary package of complete ammunition is marked so as to provide the name of the manufacturer, the identification batch (lot) number, the caliber and the type of ammunition. In addition, member states shall, by 31 December 2014, ensure the

\footnotetext{
${ }^{2}$ Directive 2008/51/EC of the European Parliament and of the Council of 21 May 2008 amending Council Directive $91 / 477 /$ EEC on control of the acquisition and possession of weapons.
} 
establishment and maintenance of a computerized data-filing system which guarantees to authorized authorities access to the data-filing systems in which each firearm subject shall be recorded. This filing system shall record and maintain each firearm's type, make, model, caliber and serial number, as well as the names and addresses of the supplier and the person acquiring or possessing the firearm. It is a missed opportunity that, in spite of the requirement of marking elementary packages of ammunition upon manufacturing, the use of such a computerized data-filing system is not required for registering, identifying and tracing ammunition within the context of the European Union.

A third weakness concerns the transportation and temporary storage of ammunition. The transportation of ammunition amongst regular freight is imprudent and undesirable considering the nature of the product. This logistical weakness may be reduced if ammunition manufacturers and dealers use only specialist carriers, certified to transport explosives. In addition, risks can be mitigated if gun manufacturers and/or dealers do not mention the contents on the packaging of firearms and ammunition. Sending arms, ammunition and weapon parts separately would also reduce the likelihood that firearms and ammunition are used for criminal purposes by malicious third parties.

\section{A Brief Comparison Between Neighbouring Countries}

This article focused primarily on the situation in the Netherlands. It is now interesting to broaden its scope and compare the Dutch legislation, policy and practice regarding ammunition to the situation in three neighbouring countries; the United Kingdom, Belgium and Germany.

Licensing laws can be categorised as being either permissive or restrictive. Licensing laws that allow all but the prohibited categories of persons to acquire guns can be called permissive, since most people are able to meet licensing requirements. Before an applicant can be denied a license or a firearm owner's identification card, the administering agency must show that the applicant is a member of one of the prohibited groups, for example under aged children, convicted felons or drug abusers. Another approach to firearms control is restrictive licensing. Under such a system a person seeking to buy a firearm, typically a handgun, must provide the licensing authority with evidence of good character and have a valid reason why he needs the firearm. In restrictive licensing, the presumption used in permissive systems is reversed: the applicant must give a sufficient reason for allowing him to have a gun rather than the licensing authority being required to show a reason for denying the request (Newton and Zimring 1969: 83). The regulation of guns in the Netherlands, Belgium, Germany and the United Kingdom can be characterised as restrictive. There are many similarities in the gun legislation and policy of the four countries, which is hardly surprising as they all implemented the European Weapons Directive of 18 June 1991 on Control of the Acquisition and Possession of Weapons and the amendment of 2008. ${ }^{3}$ Only licensed gun owners are allowed to buy guns and ammunition in these countries, although the requirements for getting a license differ, and gun dealers are obliged to keep records of each ammunition purchase, sale or transfer on behalf of a regulating authority. However, previous analysis showed that keeping records by arms dealers is not enough when regulating agencies neglect their duties, the first weakness in the ammunition crime script. Whether regulating agencies in Belgium, Germany and the United Kingdom are remiss in

\footnotetext{
${ }^{3}$ Council Directive of 18 June 1991 on Control of the Acquisition and Possession of Weapons (91/477/EEC), current to 2008 amendments (2008/51/EC).
} 
their controlling activities could not be established within the scope of this article due to a lack of empirical data.

There also exist several differences between the four countries, particularly with regard to the availability of ammunition on the domestic market. In contrast to the Netherlands, Belgium, Germany and the United Kingdom are ammunition manufacturing countries and the estimated number of privately owned firearms (absolute as well as relative) of these countries highly exceeds the private possession of firearms in the Netherlands. ${ }^{4}$ This implies a larger availability of ammunition, however, it should be mentioned that the quantity of ammunition individuals are allowed to purchase is limited by law in Belgium and the United Kingdom, whereas in Germany and the Netherlands gun owners are allowed to purchase any quantity of ammunition as long as the ammunition is suitable for the firearms that are registered on their license. A high availability of ammunition on the domestic market makes legal and illegal cross-border purchases by individuals, the second weakness in the ammunition crime script of the Netherlands, less useful and plausible.

The four countries implemented regulations for the storage of ammunition by private gun owners and governmental agencies and they all regulated the storage of firearms and ammunition in transit. ${ }^{5}$ Previous analysis of the Netherlands, nevertheless, showed a logistical weakness regarding the transportation and storage of ammunition notwithstanding the existence of specific requirements. Whether the storage and transportation of ammunition in Belgium, Germany and the United Kingdom were as imprudent and undesirable as the storage and transportation of ammunition in the Netherlands couldn't be established within the scope of this article, again as a result of a lack of empirical data.

\section{Discussion}

This article has described how ammunition may end up amongst Dutch criminals, using the perspective of a crime script. It is shown that such a structured approach leads to several useful insights for public policy. Where previous studies on illegal ammunition emphasize the need for a continuous influx of ammunition and assume that illegal ammunition is a relatively scarce commodity (Anders 2006a; Bourne and Berkol 2006; Tita et al. 2006), this analysis of the criminal purchase of ammunition in the Netherlands shows that the criminals' consumption of ammunition is limited in extent. This affects the channels through which illegal ammunition is obtained. Large-scale, cross-border smuggling activities are not necessary when criminals can easily obtain ammunition from sports shooters and when ammunition is transported and stored carelessly, as appears to be the case in the Netherlands. The finding of Bourne and Berkol (2006) that the real problem in terms of illegal ammunition lies in a combination of a weak regulatory framework with inadequate enforcement of laws and regulations is thus confirmed. Permit holders can purchase large amounts of ammunition in the Netherlands and abroad without the Dutch government knowing anything about it. At the time of writing, the police do not verify the records of ammunition sales and, because of their limited legal powers, police controls are a sham that can easily be avoided by malicious individuals. By addressing the weaknesses in the logistics of ammunition and exposing deficiencies in the knowledge and level of information of the police, as well as the

\footnotetext{
${ }^{4}$ The estimated number of privately owned firearms (per 100 population): Netherlands 510,000 (3.9), United Kingdom 4,060,000 (6.7), Belgium 1,800,000 (17.2), and Germany 25,000,000 (30.3) (www.gunpolicy.org, accessed 13 February 2012).

5 www.gunpolicy.org, accessed 13 February 2012.
} 
limitations of control and enforcement, several policy implications have been defined related to the fight against the criminal purchase of ammunition. In the short term, the implementation of an automated registration system by arms dealers and the use of a different type of carrier for legal ammunition transports would seem to be feasible and promising. In the long term, a common approach by European enforcement agencies, preferably in cooperation with the ammunition manufacturers, is indispensable to prevent the criminal purchase of ammunition.

Funding This article is based on a recently completed study (De Vries 2010) that was supported by the Police and Science Program of the Police Academy of the Netherlands.

Open Access This article is distributed under the terms of the Creative Commons Attribution License which permits any use, distribution, and reproduction in any medium, provided the original author(s) and the source are credited.

\section{References}

Anders, H. (2006a). Ammunition: the fuel of conflict. Oxfam Briefing Note.

Anders, H. (2006b). Following the Lethal Trail: Identifying Sources of Illicit Ammunition. In S. Pézard \& H. Anders (Eds.), Targetting Ammunition (pp. 206-227). Genève: Small Arms Survey.

Bourne, M., \& Berkol, I. (2006). Deadly Diversions: Illicit Transfers of Ammunition for Small Arms and Light Weapons. In S. Pézard \& H. Anders (Eds.), Targetting Ammunition (pp. 99-131). Genève: Small Arms Survey.

Bruinsma, M. \& Moors, H. (2005). Illegale vuurwapens. Gebruik, bezit en handel in Nederland, $2001-2003$. Tilburg: IVA.

Cornish, D. B. (1994). The Procedural Analysis of Offending and Its Relevance for Situational Prevention. In R. V. Clarke (Ed.), Crime Prevention Studies (pp. 151-196). Monsey, N.Y.: Criminal Justice Press.

De Vries, M. S. (2008). De handel in omgebouwde gas- en alarmwapens. Apeldoorn: Politieacademie.

De Vries, M. S. (2010). Van the instrument of delivery naar the actual agent of harm, munitie in het Nederlandse criminele milieu. Apeldoorn: Commissie Politie \& Wetenschap.

De Vries, M. S. (2011). Converted firearms: a cross-border problem with local harm. European Journal on Criminal Policy and Research, Converted firearms: a cross-border problem with local harm. European Journal on Criminal Policy and Research. http://www.springerlink.com/content/8247078777485jg0/. Accessed 6 Feb 2012.

Dienst Nationale Recherche. (2008). De illegale handel in vuurwapens en explosieven; deelrapport Criminaliteitsbeeld 2007. Woerden: Korps landelijke politiediensten.

Dreyfus, P. (2006). Crime and Ammunition Procurement: The Case of Brazil. In S. Pézard \& H. Anders (Eds.), Targetting Ammunition (pp. 172-203). Genève: Small Arms Survey.

Korps landelijke politiediensten. (2006). Vuurwapens en explosieven. Deelrapport Criminaliteitsbeeld 2005. Driebergen: Korps landelijke politiediensten.

Newton, G.D. \& F.E. Zimring (1969). Firearm Licensing: Permissive v Restrictive. In Firearms \& Violence in American Life: A Staff Report submitted to the National Commission on the Causes and Prevention of Violence (pp. 83). Washington, DC: US Government Printing Office.

Spapens, A.C., \& Bruinsma, M.Y. (2002). Vuurwapens gezocht. Vuurwapengebruik, -bezit en -handel in Nederland, 1998-2000. Tilburg: IVA.

Tita, G. E., Braga, A. A., Ridgeway, G., \& Pierce, G. L. (2006). The criminal purchase of firearm ammunition. Injury Prevention, 12, 308-311.

Van der Zee, S, \& Ham, H. (2006). Vijf jaar Vuurwapendatasysteem. Een terugblik. Zoetermeer: KLPD-DNRI.

Centraal Bureau voor de Statistiek (2011). Doodsoorzaken; niet-natuurlijke dood, diverse kenmerken. http:// statline.cbs.nl/StatWeb/publication/. Accessed 30 June 2011. 